\title{
Diseases in Bolivia: Past, Present and Future Ethnoepidemiology Problems
}

Luis HuRTADo GómeZ ${ }^{1}$

\section{RESUMEN}

En el desarrollo histórico de la medicina fueron primero observaciones aisladas las que permitieron establecer cuadros nosológicos bien definidos. Este es el caso de la enfermedad de Gaucher, descrita por este autor en 1882, sin embargo más adelante, Oberling y Woringer, en 1926, al observar la forma aguda de esta entidad en cuatro miembros de una familia intuyeron la presencia de un factor familiar responsable de esta frecuencia.

Posteriormente, la epidemiología clínica creó las bases para establecer el concepto de etnomedicina al reconocer que ciertos estados patológicos afectaban preferentemente, y a veces casi exclusivamente, a algunos grupos humanos, como las esfingolipidosis observadas en el grupo Ashkenasi del pueblo judío, llegando a establecer incluso las tasas de prevalencia para los portadores. 1:50 para la enf. de Gaucher; 1:30 para enf. de Tay-Sach y 1:200 para enf. NiemannPick A. Igualmente, en el pueblo sueco, 1:230 para la enf. de Krabbe y 1:200 para la leucodistrofia metacromática.

Por otra parte, es bien conocida la drepanocitosis afectando a la población negra así como la talasemia mayor, a poblaciones que viven en las riberas del Mediterráneo, estados patológicos que fueron considerados como un capítulo especial por el Prof. Jean Bernard de Paris con la denominación de Hematología Geográfica.

El conocimiento de las leyes de la herencia biológica y el avance en la genética molecular ha permitido comprender esta aparente preferencia étnica, al demostrar que estas afecciones son resultado de alteraciones en la constitución de secuencias de los aminoácidos de genes y, por tanto, con mayor posibilidad de transmisión cuando factores socioculturales favorecen la práctica de la endogamia en ciertos grupos de población, aunque también pueden ser observadas en forma aislada en otros pueblos, si se da una mutación genética.
Otro problema que dio renovado interés a este concepto siguiendo los trabajos de investigación del Dr. Gajdusek, fue el conocimiento del problema de salud que aquejaba al grupo lingüistico Fore del altiplano de Papua de Nueva Guinea, afectado por el "kuru", enfermedad con severa sintomatología neurológica progresiva y muerte de los pacientes después de una evolución de pocos años. Por la selectividad de daño del SNC y su sintomatología se la asimiló a otra entidad ya descrita anteriormente, la Enfermedad de Creutzfeld-Jakob (CJD), la que a su vez fue relacionada con la "scrapie" (tembladera) de las ovejas identificada por los veterinarios de Gran Bretaña desde el siglo pasado. En la búsqueda de la etiología de estas afecciones, surgió la tendencia de integrarlas con las enfermedades causadas por los llamados virus lentos de las que es ejemplo la panencefalitis esclerosante subaguda ocasionada por el virus del sarampión, así como la atribuida al virus de la rubéola, pero en el CJD todos los esfuerzos por aislar el agente infeccioso causal fueron nulos, entidades en las que se encontró más bien alteraciones morfológicas en las proteínas, a las que se llamó priones y que resultaría ser un novísimo agente patológico incluso capaz de transmitirse, pero que aún no ha logrado el consenso de todos los investigadores y cuyo rol como agente infeccioso es todavía cuestionado.

En este orden de conceptos nosológicos, es interesante la posición que asume el virus de la leucemia humana de células T (HTLV) en sus dos tipos I y II y las dos formas clínico-patológicas con las que se manifiesta en el ser humano: leucemia de células $\mathrm{T}$ del adulto (ATL) y mielopatía paraparética espástica tropical (HAM/TSP) al evidenciar, por una parte, su comportamiento propio de un virus lento y revelar, por otra parte, a través de estudios etnoepidemio-lógicos, una distribución en diferentes poblaciones del mundo y sus relaciones antropológicas de éstas al demostrar un antecedente étnico común identificado como está ya el rol de las etnias portadoras de estos virus. 


\section{Introduction}

Initially during the historical development of medicine, it were isolated observations that first permitted the description of well defined diseases. This was the case for Gaucher' s disease, described in 1882. It was only later on, in 1926 when Oberling and Woringer observed the acute form of this disease in four members of one family that the presence of a genetic factor responsible for this recurrence was suspected.

Clinical epidemiology has in the meantime provided the concepts that helped establish ethnomedicine by recognizing that certain diseases occurred predominantly, and sometimes exclusively, in certain ethnic groups, such as the case of sphyngolipidoses found in the Ashkenazy Jews. Carrier prevalence rates of 1:50 for Gaucher's disease, 1:30 for Tay-Sachs' disease and 1:200 for Niemann-Pick's disease have now been described in Sweden: Krabbe' s disease has a rate of 1:230 and metachroma-tic leucodystrophy a rate of $1: 200^{2}$.

Other well known examples are: sickle cell anemia, present in groups of African origin, and thalassemia, in populations living along the Mediterranean Sea, the existence of these diseases allowed Prof. Jean Bernard from Paris, to compile a text on Geographic Hematology.

The knowledge of heredity laws and advances in molecular genetics have facilitated understanding of ethnic predominance by demonstrating that these afflictions result from genetic changes, with greater rates of transmission in the presence of interbreeding, although they can also happen in other ethnic groups because of mutations.

The discovery of kuru, a severe progressive neurologic disease that leads to death in a few years renewed the interest in this problem following the research work of Dr. Gajdusek. This disease affects a group of people that live in the highlands of Papua New Guinea, belonging to the Fore linguistic branch. Due to the CNS symptoms present in this illness, it was considered similar to Creutzfeldt Jacob disease (CJD), which in turn is related to scrapie in sheep, identified by veterinarians in Great Britain in the last century. While looking for the etiology of these diseases the tendency was to group them among those caused by slow viruses, of which subacute sclerosing panencephalitis (SSPE), caused by measles, is an example. In the cases of Kuru and CJD, all efforts to isolate a causative agent were unsuccessful; instead, what was found was a series of morphological changes in proteins, called prions. This is a novel agent, capable of being transmitted, but whose role as an infectious agent is still questioned and is not accepted by all researchers.

In the context, human T-cell leukemia virus (HTLV) types I and II are of interest. There are two clinical presentations: adult T-cell leukemia (ATL) and tropical spastic paraparetic myelopathy (HAM/ ISP). This virus behaves like a slow virus, and has been shown, through ethnoepidemiological studies, to be distributed among various populations around the world, all of which have a common identified ethnic link.

\section{Health problems of the bolivian population}

The health problems affecting the Bolivian population are related to its demographic and geographic characteristics. It should be pointed out that its human biodiversity and distribution are the result of its history.

In general, the country can be divided into two major regions: the highlands and the tropics. The first are located high aboye sea level, the climate is cold and dry and more so as the altitude increases. Included are major cities, such as La Paz, Oruro and Potosí, located between 3,750 and 4,200 $\mathrm{m}$ a.s.l. The second region starts in the valleys to the east of the "Cordillera Oriental de los Andes" (the eastern portion of the Andes mountain range), where cities like Cochabamba, at 2,540 m above sea level, are found, and continues through the tropical lowlands that extend towards Brasil, where the main cities: Santa Cruz, Trinidad and Cobija are located between $\mathrm{O}$ and $500 \mathrm{~m}$ above sea level (Fig. 1 ).

The human biodiversity of Bolivia has been the subject of anthropological studies, taking into account socio-cultural aspects. The motivation for many of these studies is the unsolved enigma of the origin of the American man, that is to say the people that were inhabiting this region when the Spaniards arrived and who, since then, have been designated as aboriginals, but who at the present, except for some Amazon tribes, exhibit characteristics that are difficult to identify, due to racial intermingling. That is why today, the Bolivian population is considered as multiethnic and multicultural. Most studies trying to classify the various ethnic groups have used their linguistic characteristics. There are now 104 Andean ethnic groups, with three major languages: pukina, aymara and quechua and in the tropical area there are more or less 29 (Fig. 2). 


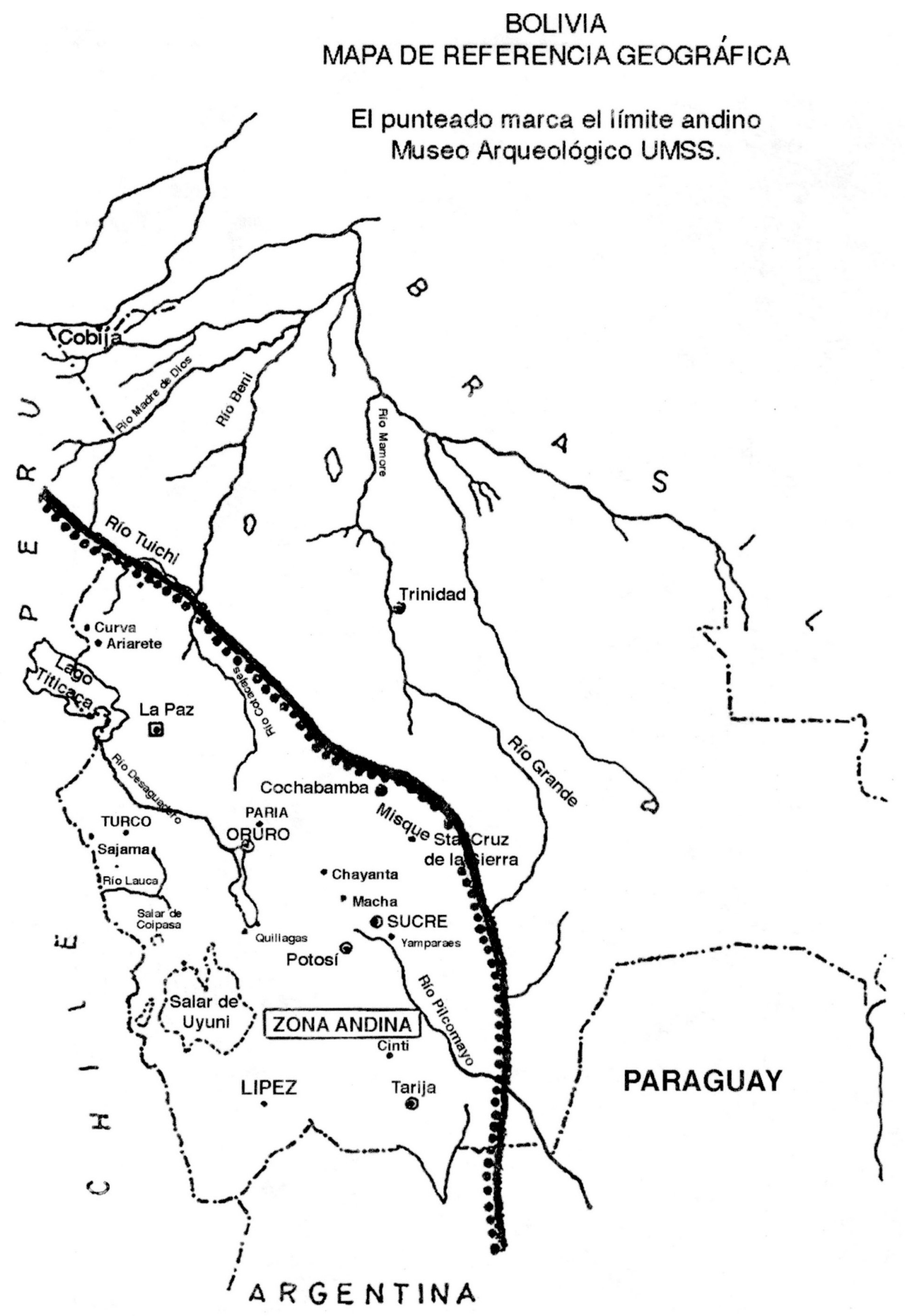

Figure 2. Phylogenetic tree of HTLV-Is based on part of the LTR region (nucleotide positions 122-628 in ATK) showing the evolutionary relationship between the new isolate from Easter Island and isolates previously reported. The tree was constructed by using the Neighbor-Joining (NJ) method. The scale at the bottom of the tree indicates the number of nucleotide substitutions per site. The horizontal branch lengths are proportional to the genetic distance, whereas the vertical branch lengths have no significance. The numbers at nodes are bootstrap values. The tree was rooted with a prototype isolate of HTLV-II, MoT (Shimotohno et al., 1985). The other DNA sequence used for construction of the phylogenetic tree have been described previously (Yamashita et al., 1998). 


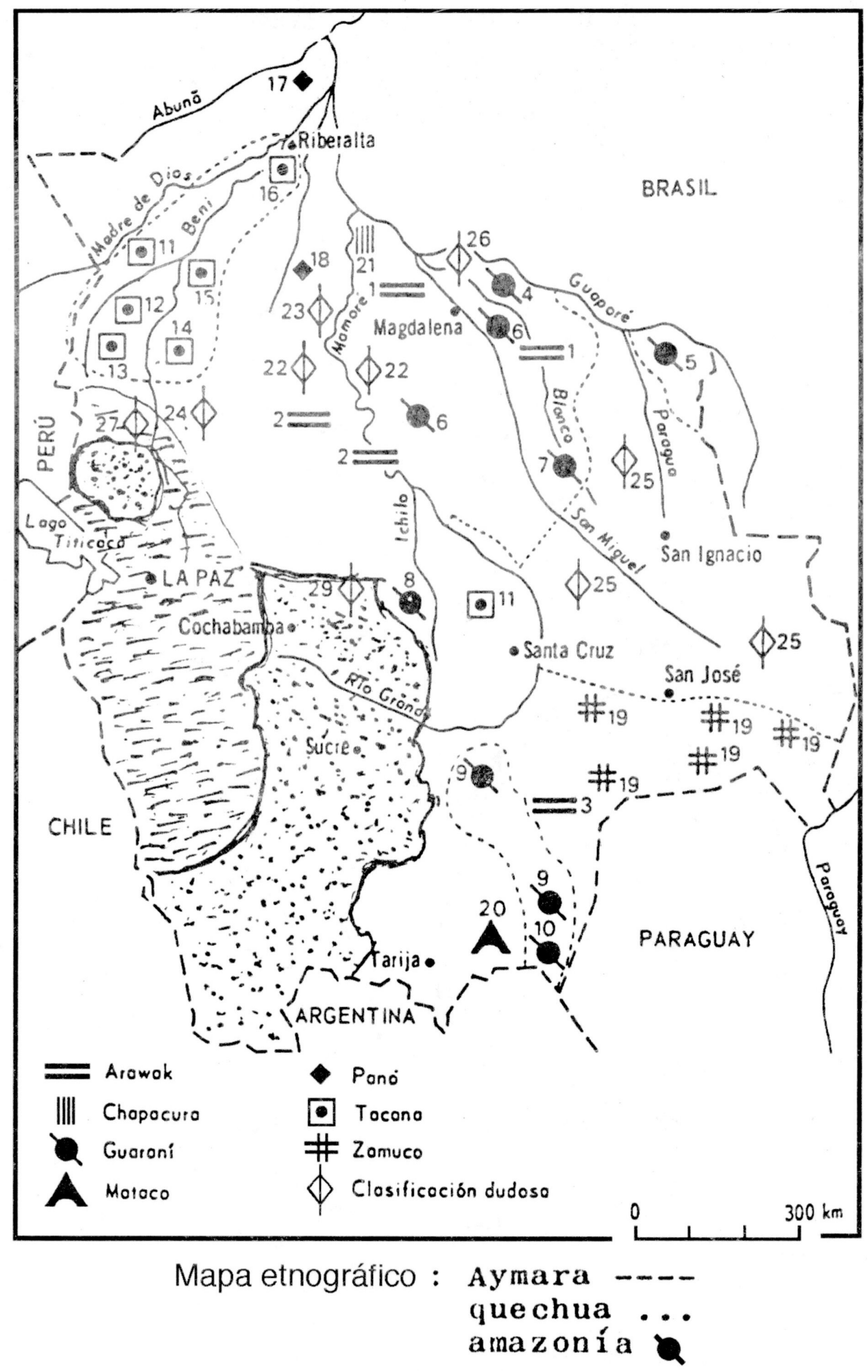

Figure 3. Phylogenetic tree of HTLV-I isolates that belong to subgroup A. The tree was constructed based on a part of the LTR region (nucleotide positions 122-628 jo ATK) by using the NJ method. EL, which is a Zairian isolate and which belongs to the Central African group, was used to root the tree. The new isolate from Easter Island is shown in reverse. For details, see the legend to figure 2. 
From the point of view of health, biodiversity is a factor that explains many of the differences encountered, besides those due to poverty, typical of third world countries.

\section{Andean region}

In the Andean region, the predominant health problems are related to adaptation to life at high altitude. One of the conditions that stands out is excessive erythrocytosis. Initial studies, carried out in Peru, identified the so-called "Monje's disease", that comprises polycythemia and a cardiac complication: cor pulmonale. This condition is usually found in older adults, but recent studies carried out at "Instituto Boliviano de Biología de Altura"-Bolivian High Altitude Biology Institute(IBBA) in La Paz, indicate that this notion has to be revised, since the condition may be found in young people, and in some cases a family history have been described. That is to say, as in many other pathological conditions, a genetic factor seems to be of major importance. In order to generate a better understanding of adaptation mechanisms and their associated pathological alterations, molecular and cellular biology studies are underway.

Another topic of interest is transient lack of adaptation by people that live at high altitudes: acute pulmonary edema may be seen especially in children, who go to the lowlands for a certain period of time, and suffer this complication upon their return to high altitude. The pathophysiology is not well understood, but the solution is easy: there is dramatic improvement upon administration of $\mathrm{O}_{2}$. It must be pointed out that there is a clear difference from the acute pulmonary edema observed in newcomers to high altitude, as described in other countries, for example as Sing in India. It is well known that the major risk for those arriving in high altitude is the pathological condition known as mountain sickness.

Another problem that has been recently attracting attention is pulmonary hypertension, initially considered responsible for acute pulmonary edema. It has been described in children younger than two years of age, and consists of changes in the right chambers of the heart, that are reversible if the child is moved soon enough to the lowlands. After a few months, when the cardiac insufficiency has been resolved, the child can return to high altitude and experience a normal development.

As the most outstanding medical and social problems we must mention pneumoconociosis and mostly silicosis, prevalent in mine workers, complicated in many cases by tuberculosis, related to inappropriate living conditions that favor the development of this disease.

\section{Tropical region}

In the tropical region, the diseases that are predominant are those transmitted by vectors such as insects and rodents. These are real public health problems because of the large number of individuals affected by, for example, leishmaniasis, Chagas disease, malaria and dengue.

1. Leishmaniasis. Researchers at IBBA have presented a summary of data obtained from international studies as well as local studies carried out in one country. The disease, included by WHO among the seven with highest priorities in the world, due to its prevalence, is characterized by a cycle that comprises three factors: the parasite (L. brasiliensis, L. mexicana, or L. chagasi); the vector, a mosquito of the genus lutzomyia; and an animal reservoir, that can be wild. such as marsupials or rodents, or domestic, such as the dog. This endemic disease is present in five of the fine departments: La Paz, Cochabamba, Santa Cruz, Beni and Pando and it is considered that one million people are at risk. Even though there is no complete epidemiological study available, there is a Bureau for the Control and Vigilance of disease related to zoonosis and vectors.

Clinically, the most common presentation is as cutaneous lesion, but in some areas mucocutaneous presentation is common with its deforming sequella. Researchers at IBBA have also identified visceral presentation.

The Division of Tropical Diseases of IBBA and ORSTOM have carried out epidemiological studies as well as an investigation concerning the natural history of the different agents. Contrary to the general belief that the disease is a consequence of the invasion of the forest by mankind, in Bolivia there seems to be a tendency for domestic transmission of the disease, since the incidence has increased in old townships and in small cities.

There is no doubt that one of the reasons for the steady increase of cases of cutaneous leishmaniasis is due to the forced migration of highland workers to the lowlands, because of a mining crisis. Epidemiological studies have shown that $50 \%$ of these workers are affected by leishmaniasis within 

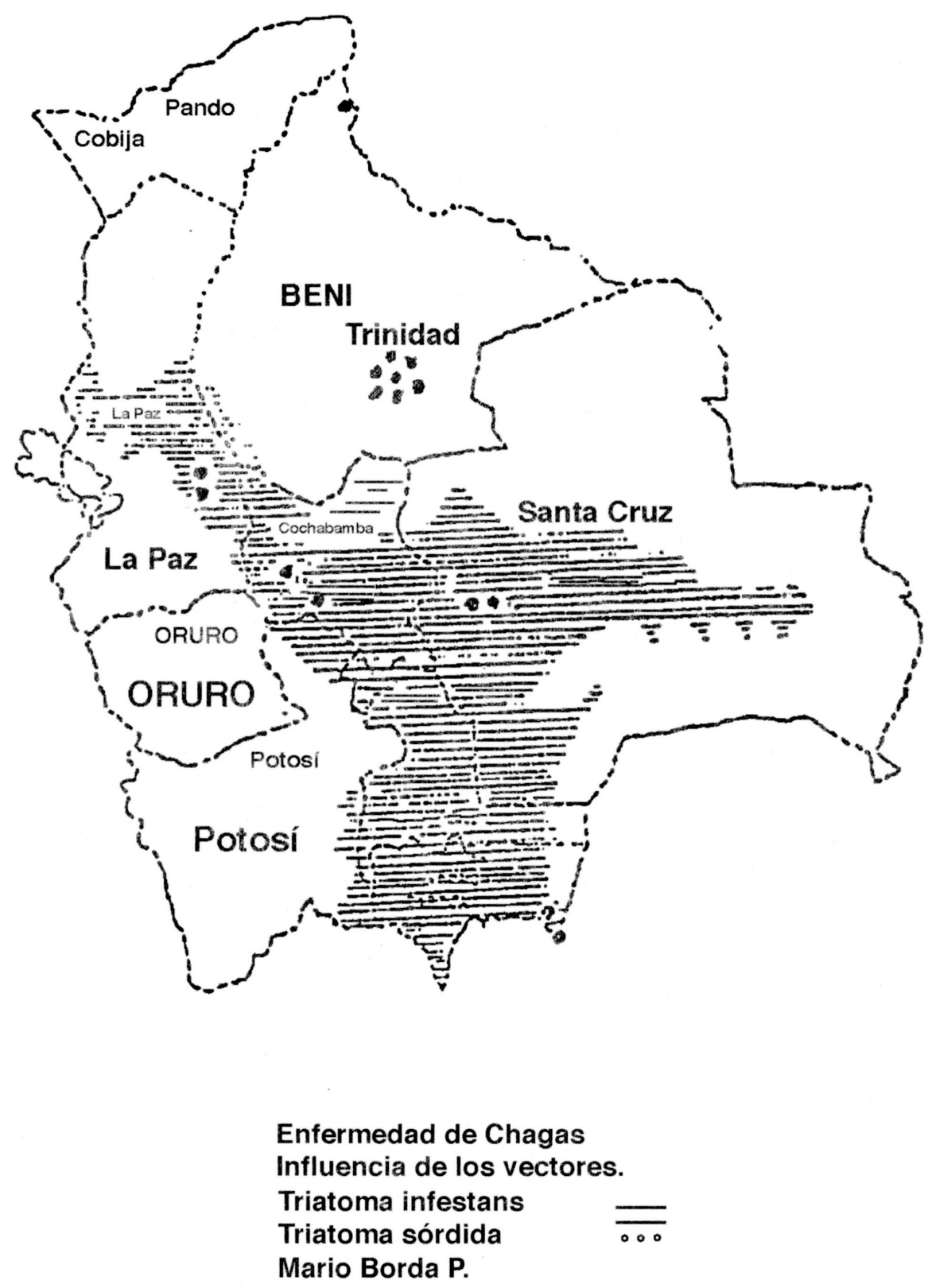

Fig. 3

the first year of their change in domicile.

One of the contributions of the studies is the performed demonstration of the utility of a plant used by the Chimane population as a traditional medicine for the treatment of this disease. Several quinoleins have been chemically isolated. It is thought that these substances may be of great therapeutic value, but due to economic constraints, they have 
not yet been developed on a commercial scale.

2. Chagas' disease, a trypanosomiasis identified in 1909 by Chagas, was described in Bolivia in 1916 by Neiva. However, the missionary father Reginaldo de Lizárraga, in 1573 noted a very accurate description of both the behavior of the vector and the origin of the disease in his "Brief Description of All of the Land of Perú, Tucumán, Río de la Plata and Chile". He writes that in all of the province of Charcas, all the way to Tucumán, there were some cockroaches known locally as "hitas", as big as ships from the north, who sting with an almost invisible needle at night, when the fires go out. Two days later a hive as big as a bean appears, which in those who "do not have a good armour it becomes an ulcer that gives them great sorrow". Since the natural history of Chagas disease does not include ulcers, we can interpret those as secondary infections due to scratching.

In Bolivia, the vector Triatoma infestans has been known since colonial times, and its local name, "vinchuca", is derived from quechua "huichucuy" which translates as "letting itself falle" which refers to the fact that this insect falls from the ceiling to the beds that are in the room.

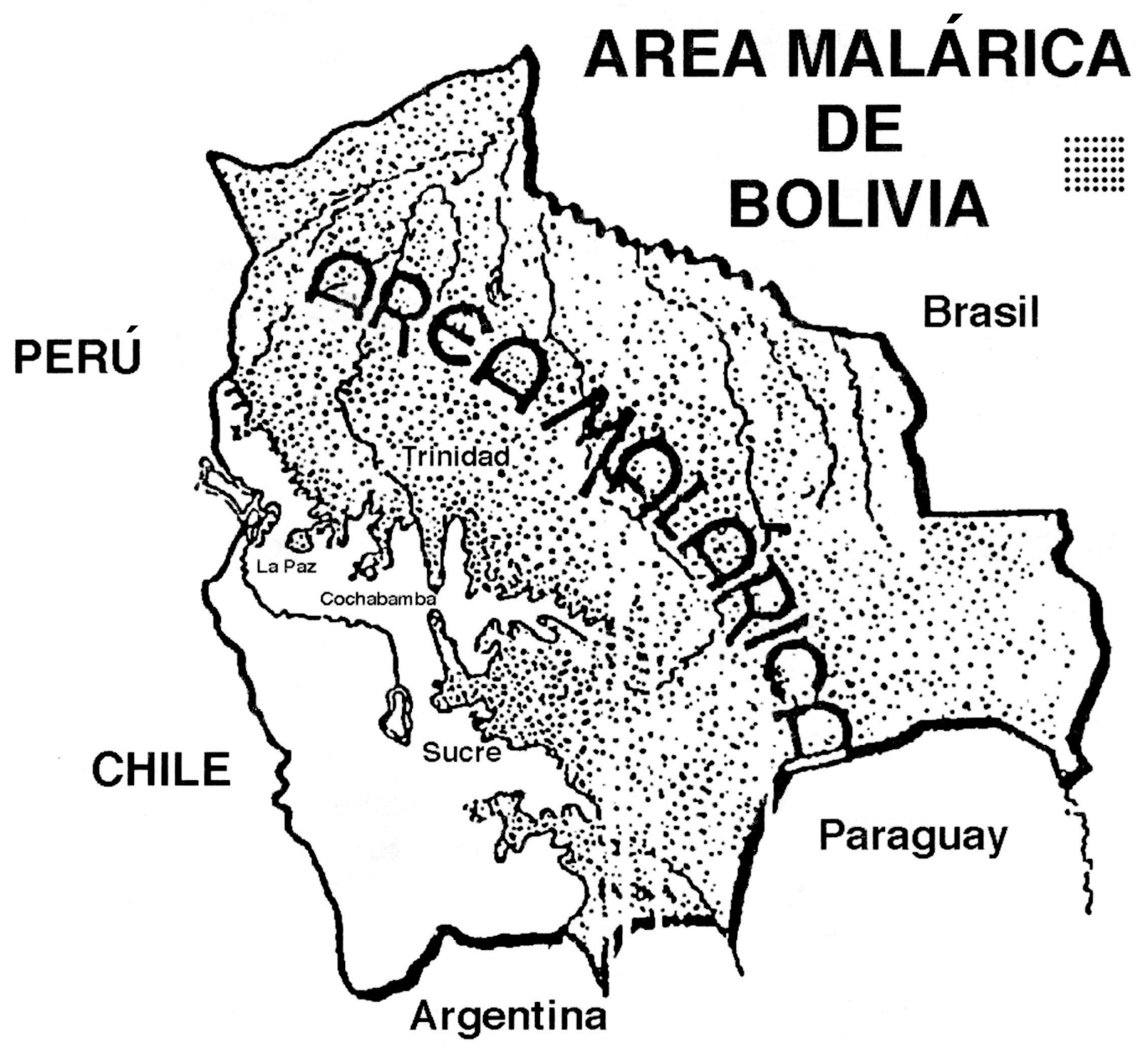

Fig. 4 


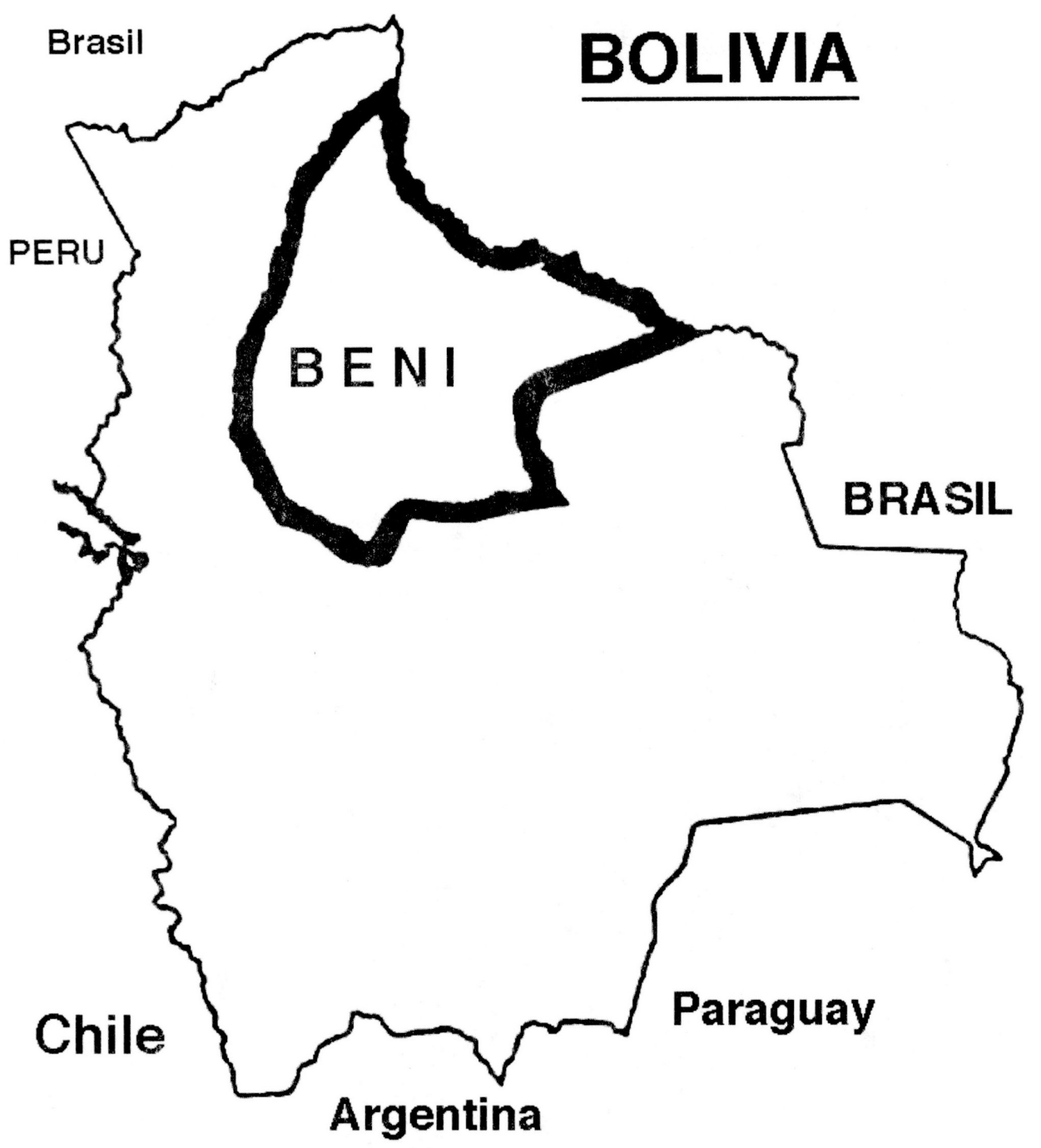

Fiebre Hemorrágica Boliviana

Localización: Depart. BENI

Fig. 5

Rafael A. Torrico described in 1943 the first acute case, with eye and lymph node involvement. Other physicians had demonstrated the presence of infested triatomas in the "Yungas" (tropical region) of La Paz as well as Tupiza, Tanja and other regions.

The importance of this disease can be gleaned from the fact that transmission occurs in $63 \%$ of the territory and that $55 \%$ of the population is at risk. According to WHO, more than 22 new cases are registred every day. In seven of the nine departments of Bolivia, 75 localities were found in which Triatoma infestans and Triatoma sordida had been identified (Fig. 3)

The studies being carried out by IBBA focus on 
new technologies to establish the genetic make up of the population and to identify wild varieties of potential vectors that could carry the disease, such as T. infestans silvestre, T. sordida, T. guasayana, $T$. brasiliensis, Pnastrongylus rufotuberculatus, and $T$. Rhodnius stali, etc.

3. Malaria. This has become the most important disease transmitted by animal vectors in the last few years due to the increase in its incidence. The vectors are: Anopheles darlingi and $A$. pseudopunctipenis.

The agents are Plasmodium vivax, found in 75 to $97 \%$ of the country (which makes it the predominant agent) and Plasmodium falciparum with a range of 3.3 to $25 \%$. With regard to environmental factors, it has been demonstrated that the lowlands of Pando, Beni and the northern areas of La Paz, Cochabamba and Santa Cruz, which have high temperatures, high humidity and abundant rains, provide excellent habitats for Anopheles darlingi, which ensures year long transmission. The southern regions are drier, the transmission is seasonal, and the main vector is Anopheles pseudopunctatus. The valleys have similar conditions to the southern regions.

In the last few decades strict control policies have been implemented and it was thought that the disease had been eradicated. The recent increase in the number of cases demonstrates that vigilance programs are no longer efficient. In 1991, 19,031 cases were reported, 17,921 due to $P$. vivax and 1,110 due to P. falciparum. In 1997, there were 51,478 and 46,097 cases, respectively.

The problem is much greater if we take into account that only one fifth of the total cases are seen in health facilities, which means that an estimated 257,390 people are affected with all the negative economic consequences that this implies.

The worsening of the epidemiologic profile can be attributed to the fact that there is no government budget allocated, a lack of laboratory supplies and drugs, and limited and sporadic control coverage (Fig. 4).

4. Dengue. According to experts of the National Center for Tropical Diseases (CENETROP) in Santa Cruz, the incidence of dengue has increased to become a public health problem.

Historically, there was an epidemic in Santa Cruz in 1930-31. In 1,987 there was another with 1,994 cases and also again in 1,988 with 4,847 patients. In following years only a few patients suspected of having the fever were admitted to hospitals. Motivated by the epidemic outbreak of 1,994, however CENETROP developed an epidemiological surveillance system in order to control possible outbreaks with the additional objective of documenting possible silent transmission of the virus. A study of 522 cases between January 1996 and April 1997 revealed 233 of them (44.6\%) to be positive. Using PCR. the virus DEN - 2 was identified and in the CDC of Puerto Rico it was found to belong to the genotypic variety Jamaica.

\section{Bolivian hemorrhagic fever}

In 1959, the first case of a rare, and until then unknown, disease was registered in the eastern area of Bolivia, specifically in San Joaquin, in the province of Mamoré and department of Beni, with similar symptoms to hemorrhagic fever. In 1960 there were 21 reported cases. It spread to other provinces, and by 1962 there were 448 cases reported, with a case mortality rate of $30 \%$ (132 people died). The incidence increased until 1964, but thanks to preventive measures it then decreased significantly duning the second semester of that year. Subsequently, only isolated cases have been reported.

American institutions such as the Middle America Research Unit (MARU), the "Comisión Mixta Boliviano Norteamericana" (Joint Bolivian American Commission) and the National Institutes of Hygiene of the Public Health Service of the USA, had taken on interest in this disease, until finally the virus was isolated. It was recognized to be different from the Argentinian Junin Fever virus, even though both are related to the Tacaribe virus which was isolated from the brain of an Aribeus bat found in Trinidad Island. The new virus was named Machupo, aften the river that is near the area of San Joaquin.

Hemorrhagic Bolivian fever can be considered a typical emerging disease, related to ecologic changes due to man. The reservoir of the virus is a mouse of the species Calomys Callosus, where proliferation has been attributed to three factors: 1 . The indiscriminate hunt of felines and the growth of wild vegetation near human habitats; 2 . floods that could not be controlled; 3. burning of grass land which resulted in the migration of rodents.

Transmission could take place through aerosols produced by the animal during defecation, miction or even while feeding. Transmission through saliva, feces and blood is also considered possible.

This disease is being monitored through an epidemiological survey, and its yearly incidence is 
very low. Following Prof. Jean Bernard's, criteria it can be considered a geographical disease as it has only been observed in Beni (Fig. 5).

\section{Problems of ethnomedicine}

Among the historic occurrence of diseases in our continent, the first to be considered is syphilis. Its origin has been attributed to contagion from Hispanic conquerors through their contact with the aboriginal American people, though this is still a subject of debate. In any case, this would be an example of an emergent, on re-emergent, disease for Europeans of that period; similar to the cases of smallpox and measles for the natives, who were decimated by such diseases from which they suffer a high mortality rate. In orden to replace them, large numbers of slaves were brought over from Africa, which resulted in a radical change in the demographic structure of the American continent.

Their introduction into Bolivia is of interest regarding probable ethnomedical problems from the Black population. Data from the 1611 census carried out by the "Audiencia de la Plata" (The La Plata Audience) showed that Potosí, where the "Cerro Rico" (The Rich Mountain) was in the apogee of silver exploitation, had a population of 160,000 inhabitants, with 66,000 Indians, 35,000 Spaniards, 40,000 foreigners and only 6,000 Blacks and "Zambos" $(3.9 \%)$. This due reflects a decimation of the imported Black population in Potosí, thought to be the presence of sickle cell anemia, related to hemoglobin $\mathrm{S}$, which caused disease when they were exposed to the hypobanic hypoxia of a region located $4,000 \mathrm{~m}$ above sea level. Today there is no Black population in Potosí, whereas in the region of Yungas of La Paz, located at 1,200 m above sea level, there are ghettoes of black people who work in agriculture.

Advances in molecular biology and its application to genetics have created a new focus in the study of such problems. The French researcher, Croigner, has submitted a 10 year project to IBBA to study not only the economic and socio-cultural characteristics of Bolivian ethnic groups, but also to analyze their genetic make-up.

In this context, clinical and epidemiologic studies on HTLV- 1 or 2 are particularly important, since they have permitted a working hypothesis to establish which ethnic groups correspond to the paleomongoloids who arrived in the first migratory waves, and being carriers of the virus, transmitted them to their descendants.

\section{HTLV 1-2 in Bolivian population}

A study performed by Japanese researchers, led by Professor Dr. Shunro Sonoda from the Kagoshima University in collaboration with INLASA (Instituto Nacional de Laboratorios en Salud, La Paz) was the beginning of a fascinating phase in phylogenetic studies of American ethnic groups, and particularly those in Bolivia.

In the last five years more than 317 peripheral blood samples from military recruits, healthy blood donors, native people living in the Bolivian Andes highlands and also patients with spastic paraparesis were examined for HTLV-UII. About $2 \%$ of the general population proved seropositive for HTLV-I but not for HTLV-II. Two major foci were found among Aymara and Quechua people. The prevalence in Aymara's from Huachacalla, Escara and Llica was $14-18 \%$ of HTLV-I infection including patients with spastic panapanesis, and $11 \%$ in Quechua's from San Juan. The negative results in many other villages suggest that HTLV-I carriers were geographically isolated in central and southern Bolivia. Clinically all the patients positive for HTLV-I infection present with spastic panapanesis (HAM/ TSP) and until now no adultT-cell leukemia (ATL) has been found. Of the 14 cases of HAMITSP only three were women.

This findings are in contrast with the Japanese and Caribbean data, where ATL and female predominance are encountered.

The genetic background of this population is characterized by HLA class 1 (ACB) and class II alleles but HAM/STP patients were mixed from the South American mongoloid and Caucasoid groups, while Asymptomatic HTLV Carrier (AC) appeared to mention the identity of a mongoloid HLA background.

There are several connotations to these findings:

a) Is the Aymara people the most ancient and therefore related to the paleomongoloids?

b) Do positive cases among non-Aymara people correspond to unknown cross breeding?

c) Are the Aymara-speaking populations representative of an ethnic group that maintains its purity?

Further studies are necessary to answer these questions. With the help of this group of Japanese researchers a unit of molecular biology will now be onganized in INLASA to this end. 


\section{REFERENCES}

AGUILO, F.

1992 Aborígenes de América. Fondo Rotatorio Editorial. Cochabamba, Bolivia.

ALBO, J., LIBERMANN, K., GODINEZ, A. y PIFARRE, F. $1990 \quad$ Para comprender las culturas rurales en Bolivia. Ministerio de Educación y Cultura CIPCA Unicef. La Paz-Bolivia 2da ed.

ANTEZANA, G.A. y col. Edema agudo pulmonar de altura, 1988 IBBA Anuario. La Paz Bolivia, 15-23.

BERNARD, J 1973 Hématologie Géographique in 973 Grandeur et Tentations de la Médicine. Ed. Buchet/Chastel Paris.

BOERO ROJO, H. Geografía in Enciclopedia "Bolivia Má1993 gica”. Ed. Vertiente La Paz. Bolivia T I: 24-77.

BRENIERE, S.F. (Orstom), REVOLLO, S. (IBBA). 1997 Epidemiologie Moleculaire des Agents de laMaladiedeChagasetdes Leishmanioses. Information Generale. Departement des Maladies Tropicales. IBBA La Paz. Bolivie.

CHUNGARA, M.J. La Enfermedad de Chagas. Salud Pública 1993 Boliviana. Sociedad Boliviana de Salud Pública 32(52): 164-74.

CRIALES, H.A. $\quad$ La Raza Negra y su Desaparición de Poto1995 sí. Archivos Bolivianos de Historia de la Medicina. La Paz-Bolivia. Vol $173-86$.

DOROZYNKKI, A. Le Plus Grand Bouleversement Ecologic 1992 de l'Histoire Science et Vie. Paris, Oct

DUJARDIN, J.P., NOIREAU, F. Ecogénetique des Vecteurs de 1997 la Maladie de Chagas. Departement des Maladies Tropicales.Information Generale. IBBA. La Paz-Bolivie.

DUJARDIN, J.P., LE PONT, F., TORREZ, M. Leishmanioses: 1997 Facteurs de Risques et Auto-protection. Departement de Maladies Tropicales. Information Generale IBBA, La Paz.

EVIA, R.J. 1995 Fiebre Hemerrágica Boliviana.Boletín Epidemiológico Ministerio de Desarrollo Humano. Secretaría Nacional de Salud Dirección General de Vigilancia y Control de Enfermedades y Riesgos, La Paz, Bolivia N¹46, 2-5.

FOURNET, A., HOCQUENILLIER, R. IiANTIER, J.C.H. 1995 Combattre la Leishmaniose. La Recherche, avril. Vol. 26, 424-429.

GIANELlA, A., et al. Dengue en Santa Cruz de la Sierra. Bo1998 letín Científico del CENETROP 16:6-10.

HURTADO GOMEZ, L. Insufficence cardiaque du nourrisson 1966 et hyposie d' altitude. Hygiene et Médicine. Geneve 24: 224-26.

HURTADO GOMEZ, L. Edema Agudo de pulmón en la Altura 1997 in Pediatria Meneghello. Ed. MédicaPa- namericana. Buenos AiresT 1: 1341-1347.

IKEDA, M., YOSHIDA, S. Epidemiology and Cultural 1996 Anthropology their Possible Collaboration. Etbnoepidemilogy of Cancer. Japan Scientific Societies Press, Tokyo. CRC Press.

KILGORE, RE., et al. Treatment of Bolivian hemorrhagic fever 1997 with intavenous ribavirin. Clinical Infectious Disease. 24: 718-22.

LIBERT, J., VAMOS-HURWITZ, E., LOEB, H. Les 1980 sphingolipidoses. Encycl. Mid. Chir. Paris Pédiatrie, 4059 M 10, 9.

MOLLINEDO LL., RE. Informe Situación de la Malaria en 1997 Bolivia. Jefe Nacional. Servicio de Vigilancia y Control de la Malaria Ministerio de Salud Pública.

MONGE, C., ARREGUi, A., LEON-VELARDE, F. 1992 Pathophysiology and epidemiology of chronic mountain sickness. Int. J. Sports Med. 13: S79-S81.

PEREDO, C., et al. Detección de Casos Autóctonos de Ma1998 lana Urbana por P. Vivax en Barrios del Plan 3000, Santa Cruz-Bolivia. Boletín Científico del CENETROP Santa Cruz de la Sierra-Bolivia 16: 11-15.

ROWLAND, RS. Constitutional disturbances of Lipid 1952 Metabolism in Brenemans. Practice of Pediatrics, V111-28: 15-84.

SONODA, S., et al. Informe preliminar.

SUAREZ FERNANDEZ, G. Nueva formna de acción infeccio1997 sa. El Prión y las encefalopatías espongiformes. Annales de la Real Academia Nacional de Medicina. T CXIV cuaderno segundo p 309-330.

TORREJON, J.E. Primeras referencias sobre la enfermedad 1995 de Chagas-Mazza y su vector entre Charcas y El Plata. Archivos Bolivianos de Historia de la Medicina. La Paz -Bolivia. Vol 1 (2): 205-206.

VILLENA, M., VARGAS, E., NIGON, M. Eritrocitosis exce1997 siva. Instituto Boliviano de Biología de Altura.(IBBA) Departamento de Biología, Fisiologia y Patología de Altura Informes. La Paz, Bolivia.

VILLENA, M. and AL. Desadaptación Crónica a la Vida en la 1997 Altura. XIX Congreso Latinoamericano de Ciencias Fisiológicas. Revista de la Fac. de Medicina, Caracas-Venezuela, vol 20-1, 14.

WALKER, D. L. Agents in Slow Virus Infections Report 1973 of the Sixty-Fourth ROSS CONFERENCE of Pediatric Research. Copyright-Ross Laboratories. 
